\title{
Comparative Analysis on Seismic Provisions of the National Structural Codes of the Philippines (NSCP) 1992 and 2010 as Applied to the Design of Reinforced Concrete Public School Building
}

\author{
${ }^{1}$ Resurreccion Villa Garrote \\ ${ }^{2}$ Rizalyn C. Ilumin
}

\author{
${ }^{I}$ Dean-College of Engineering and Architecture \\ Pangasinan State University, Urdaneta City \\ Pangasinan, Philippines \\ ${ }^{2}$ Faculty-Department of Civil Engineering \\ Pangasinan State University, Urdaneta City \\ Pangasinan, Philippines
}

Abstract-The main target of this research work is to show the differences of the National Structural Codes of the Philippines (NSCP) Seismic provisions of the 2 codes-NSCP 1992 and the new one, NSCP 2010. In order to work out for the main differences of the Design Base Shear (V), the Linear Static Analysis (LSA), which is considered as the Static Lateral Force Procedure and the Response Spectrum Analysis (RSA), another method specified in the NSCP codes under the Dynamic Lateral Force Procedure were carried out to analyze a Three Storey Reinforced Concrete Public School Building. In the Dynamic Analysis, the maximum ground motion intensity, such as the peak ground acceleration $\left(A_{\max }\right)$ of the earthquake is considered.

The outcome of this research work is an indispensable tool for Structural Designers who will assess the seismic hazard of existing buildings designed under the NSCP 1992 in terms of their structural integrity. While the structural designers' liability is not limited to design flaws, it is their utmost concern to determine if there are deficiencies in their Seismic design criteria based from the National Structural Code of the Philippines. It is hoped that this research work will guide the Structural Designer in recommending structural strengthening and retrofitting of existing buildings which were designed under NSCP 1992.This is to enhance structural integrity of buildings thus, life threatening seismic hazard not only in School Buildings but all existing buildings as well can be minimized if not eliminated. The major findings of the research study are the effects of the Seismic Provisions of NSCP 2010 on the value of Design Base Shear which is greater than the effects of NSCP 1992 Seismic Provisions, the Elastic Response Parameters of Structural elements have resulted higher values in NSCP 2010 than in NSCP 1992 Seismic Provisions and eventually resulted to bigger sections and higher reinforcement index of structural elements in NSCP 2010 than in NSCP 1992.

In the light of these findings and conclusions of this research, the NSCP 2010 seismic provisions imposed on the Three- Storey Reinforced Concrete School Building have resulted higher values of Design Base Shear V than in NSCP 1992 thus it implied that NSCP 2010 were more conservative and cautious in terms of the safety and structural integrity of the school building during seismic events. The higher values of elastic response parameters and the larger sizes of structural elements and higher reinforcement index in NSCP 2010 enhance the structural safety of the Three-Storey Reinforced Concrete School Building against severe earthquake, and its structural safety were given due consideration under the seismic provisions of NSCP 2010 wherein it should not collapse but with minimal non-structural damage only during a severe earthquake while NSCP 1992 provide more emphasis on the economic aspect of design but with greater possibility of structural damage and even collapse during the occurrence of the same earthquake.

Keywords-Base Shear, Elastic, Response Spectrum, Seismic

\section{INTRODUCTION}

The Philippines is located within the Pacific Ring of Fire and belongs to the most earthquake prone region in the world making it to be very vulnerable to seismic hazards. The poor performance of concrete buildings has been demonstrated dramatically in the July 1990 Luzon earthquake especially in the cities of Baguio and Dagupan. These two (2) cities suffered the most devastation and many seismic hazards like collapsed buildings and bridges, landslide and liquefaction were observed. With these devastations, the loss of life \& limb and loss to properties attributed to the collapse of structures specially buildings, the Association of Structural Engineers of the Philippines reassessed and revised the National Structural Code of the Philippines (NSCP) $19873^{\text {rd }}$ edition which is the existing design code before the occurrence of the 1990 Luzon earthquake. Thus, after 2 years, the NSCP 1992 $4^{\text {th }}$ edition were published.

The July 1990 Luzon earthquake exacted a heavy toll in the human, economic, and social resources 
of the Philippines at a time when she was struggling for economic development (F. Yamazaki, et. al p.6031). By then, there were periodic revisions of the NSCP especially on its Seismic provisions, the NSCP 1992, NSCP 2001, and the most recent is the NSCP 2010. According to A. Oreta (2006),"Although our present structural design codes may have incorporated special provisions for the earthquake resistant design of new buildings, there is still a danger of possible collapse or life threatening damage in existing buildings specially the old ones" (p.186-187).Hospital and school buildings which were considered essential structures under the said codes, needed urgent evaluations on their expected performance against major earthquake. This is to avert more devastations and loss of life and properties. Past seismic hazard studies for the Philippines, based on historical earthquakes, were made by Molas \& Yamazaki (1994). Torregosa et al. (2001) used both historical earthquakes and active faults as basis for seismic hazard assessment in the Philippines, but no published report yet regarding the assessment of the different NSCP codes seismic provisions. Goel and Chopra (1991) have their Evaluation of the US Seismic Provisions for Asymmetric-Plan Systems. With that study, it is the intent of US seismic codes that buildings suffer no damage during some usually unspecified level of moderate ground shaking. The reduction factor $\mathrm{R}=1.0$ implies that the design base shear $\mathrm{V}$ of the corresponding symmetric-plan system is just sufficient for it to remain elastic during excitation. A parallel research work were done by Luca Ongaro (May, 2007) in her dissertation entitled "Comparing Italian Seismic Codes for Design of RC frame buildings. "The results of her study, comparing D.M. 16.01.1996-Norme Techniche per le Costruzioni in Zone Sismichi and OPCM 20.03.2003-Ordinanza del Presidente del Consiglio del Ministri-the DM code, advises or partially applies the seismic concepts, but it does not force the designer to understand the importance of these performance requirements. On the other hand, the design guidelines in OPCM code force the designer to account for good structural performance in order to produce structures which are feasible from economical point of view." (Ongaro, 2007 p.144)

The main target of this research work is to show the differences on the seismic design provisions of the National Structural Codes of the Philippines by proposing a comparative analysis of the 2 codes, the NSCP 1992 and the new one, NSCP 2010 as applied to the Design of Three-storey Reinforced Concrete Public School Building.

The main concern of the structural designer is to design buildings or any structure that will become earthquake resistant in seismically active areas based on existing codes. Different design codes have been explored and prepared in our society's quest to produce structures that will be safe during an earthquake. The structural analysis and design procedure can be organized according to their basis as generally relating to forces, moments and displacements which were referred to under the NSCP codes as Elastic Response Parameters (ERP) of the structures.

The new Structural Code which is the NSCP 2010, with emphasis on the seismic design provisions set a more realistic value of Design Base Shear (V) which is the total lateral force or shear at the base of the structure. The Design Seismic Force as provided for in the two codes is the minimum total strength design base shear (V). The new code integrated additional parameters to be used in determining such function as the design base shear.

This function is considered to be the most critical in Seismic Analysis and Design. Under the new code, upper and lower limits of $\mathrm{V}$ were considered, while it was not considered under the provisions of NSCP 1992. This code adopted the Uniform Building Code (UBC) 1988 in which case the $\mathrm{V}$ is to be determined by only one empirical formula while in NSCP 2010, the same V will be determined by four (4) empirical formula in Seismic Zone 4 and three empirical formula in Seismic Zone 2. This new code adopted its seismic provisions from UBC 1997 where maximum moment magnitude (M) of an earthquake was considered while in NSCP 1992, the said provision was not considered. The parameters that were given due consideration in NSCP 1992 were limited to seismic zone, importance factor of the structure, numerical coefficient of building frame system, site coefficient for soil characteristics and fundamental period of vibration of structure. Although, in the NSCP 2010, the aforementioned parameters were also considered, but there are additional factors that were taken into account, like seismic coefficients, $\mathrm{Ca} \& \mathrm{Cv}$, near source factors, $\mathrm{Na} \& \mathrm{Nv}$ and moment magnitude M. 


\section{OBJECTIVES OF THE STUDY}

The main target of this research work is to show the differences of the provisions of seismic analysis and design of structures under the National Structural Codes of the Philippines (NSCP) by preparing a comparative evaluation of the 2 codesNSCP 1992 and the new one, NSCP 2010 in applying to the Design of Multi-Story Public School Building.

\section{RESEARCH DESIGN AND METHODOLOGY}

In order to work out for the main differences of the Design Base Shear (V), the Linear Static Analysis (LSA), which is considered as the Static Lateral Force Procedure and the Response Spectrum Analysis (RSA), another method specified in the NSCP codes under the Dynamic Lateral Force Procedure were carried out to analyze a Three Storey Reinforced Concrete Public School Building. In the Dynamic Analysis, the maximum ground motion intensity, such as the peak ground acceleration $\left(\mathbf{A}_{\max }\right)$ of the earthquake among other parameters were considered.

The structural design application for some critical structural elements were carried out also using Ultimate Strength Design principles conforming to American Concrete Institute (ACI) codes as adopted by NSCP. This is integrated in the analysis and design output using Structural Analysis and Design Program (STAAD.Pro) software. The main target of the aforementioned design applications is to point out differences between the seismic performance of public school buildings designed under NSCP 1992 and NSCP 2010. Also the balance between a good seismic performance and economy in the structure is also taken into account. The NSCP 1992-Section 2.2 "Lateral Forces" and NSCP 2010 Section 208 " Earthquake Loads " are also described in this research work to highlight its similarities and differences.

The descriptive-comparative method was chosen to suit the required methodology. This is the most appropriate method in this study which seeks to establish the differences of the effects of Seismic Provisions between NSCP 1992 and NSCP 2010 structural codes as applied to the analysis and design of a Three Storey Reinforced Concrete School Building. The analytical procedures using STAAD.Pro software were used to determine the values of the Elastic Response Parameters (ERP) as well as the required cross sections and reinforcements of the most critical structural elements.

The values of design base shear $\mathrm{V}$ were determined from the formula as provided for in the two Codes. Different data were derived from the analytical procedure which were carried out in the Seismic Analysis of a Three Storey Reinforced Concrete School Building as proposed in this study. The two methods described in the two NSCP codes Seismic Provisions are the Linear Static Analysis (LSA) and Response Spectrum Analysis (RSA). Values of ERP of the different structural elements in the two orthogonal frames which were considered to be the most critical frames were compared and presented in tabular form. The analysis of gravity load, the Structural Analysis and Design Program STAAD.Pro software was used which is an additional loading requirement for the design of some critical elements of the aforementioned building. In the structural design of the said building, the ultimate strength design (USD) principles under the American Concrete Institute (ACI) was considered. The said Seismic Analysis and Design was prepared to conform with NSCP 1992 and a similar Analysis and Design was prepared to conform with NSCP 2010.A comparative analysis of the design output of the most critical beams, girders and column sections was presented in tabular form.

The difference in values of the design base shear $\mathrm{V}$ as determined under the two codes was analyzed using the tests of significance of a difference as the statistical tool. The different values of elastic response parameters and cross sections of the most critical structural elements as determined under the two codes were compared and analyzed if their differences are significant using the arithmetic average or mean and tests of significance of a difference as statistical tool.

\section{STRUCTURAL MODELING AND ANALYSIS PROCEDURES}

Analysis procedures. Both NSCP 1992 and NSCP 2010 provided two seismic analysis options for the design of buildings namely: the static lateral force procedure and the dynamic lateral force procedure, both with specific conditions as indicated in its provisions, Sections 208.4.8.2 and 208.4.8.3. 


\section{Static Lateral Force Procedure or Linear Static Analysis (LSA)}

The structure is modelled as linearly elastic with secant stiffness through the yield point. It is performed under a set of lateral static forces applied at floor levels separately in two orthogonal horizontal directions. The intent is to simulate through these forces the peak inertia loads due to the horizontal component of the seismic action in two horizontal directions. The magnitude of the loads is intended to result in the deformation demands which would be caused by design seismic force. This design seismic force is defined as the minimum total strength design base shear, factored and distributed in accordance with the codes. Fundamental assumption in this method is that the structural components possess infinite inelastic deformation capacity. The factor method is one method in seismic analysis under the static force procedure will be used. It is applicable to those structures that have a response not significantly influenced by higher modes of vibrations, and this usually happens when the structure is regular in plan and elevation. Regular structures have no significant physical discontinuities in plan or vertical configuration or in their lateral-force-resisting systems as defined both in NSCP 1992 and 2010.In the LSA, the forces are linearly distributed along the height and it is assumed a linear deformed shape of the structure. Under seismic loading, the structure shows global cantilever behaviour with a predominant flexural or shear shape depending on the relative stiffness of the vertical or horizontal elements respectively.

The Design Base Shear V is computed using the formulas as given in Section 2.2.5.2.1 of NSCP 1992 and in Section 208.5.2.1 of NSCP 2010.

The total force shall be distributed over the height of the structure in conformance with the following equations as provided for in both NSCP codes.

$V=F_{t}+\sum F_{i} \quad, \quad F_{t}=0.07 T V, F_{t}$ need not exceed $0.25 \mathrm{~V}$ and equals zero if $\mathrm{T}=\mathbf{0 . 7 0}$ seconds or less.

$T=C t H^{3 / 4}, \mathrm{C}_{\mathrm{t}}$ are values depending on the structural type $\mathrm{H}$ is the total height of the building.

$$
F x=\frac{(V-F t) w x h x}{\sum w i h i}
$$

\section{RESULTS AND DISCUSSIONS}

The seismic provisions of NSCP 1992 \& 2010 which contained the requirements for seismic analysis of structures varies in some parameters including empirical coefficient.

Table 1 shows some deviations and amendments in the formula for the Design Base Shear

Table 1 Comparison on the Provisions of Seismic Analysis and Design Parameters:

NSCP 1992 and NSCP 2010

\begin{tabular}{|c|c|c|}
\hline $\begin{array}{l}\text { Seismic } \\
\text { Analysis \& } \\
\text { Design } \\
\text { Parameters } \\
\end{array}$ & NSCP 1992 & NSCP 2010 \\
\hline \multirow{4}{*}{$\begin{array}{l}\text { 1.Design } \\
\text { Base Shear } \\
\text { (V) }\end{array}$} & \multirow{4}{*}{$\mathbf{Z I C} / \mathbf{R}_{\mathbf{w}}(\mathbf{W})$} & $\mathrm{C}_{\mathrm{V}} \mathrm{I} / \mathbf{R T}(\mathbf{W})$ \\
\hline & & $2.5 \mathbf{C}_{\mathrm{a}} \mathrm{I} / \mathbf{R}(\mathrm{W}) \quad$ Upper Limit \\
\hline & & Lower Limit \\
\hline & & $\mathbf{0 . 8 0 Z N}_{\mathbf{v}} \mathbf{I W} / \mathbf{R}$ Lower Limit \\
\hline $\begin{array}{l}\text { 2. Numerical } \\
\text { Coefficient } \\
\text { of structural } \\
\text { material }\left(C_{t}\right)\end{array}$ & $\begin{array}{l}\text { 0.085 for Steel MRSF } \\
0.075 \text { for Reinforced } \\
\text { Concrete MRSF \& } \\
\text { Steel EBF } \\
\text { 0.050 for all other } \\
\text { structure } \\
\end{array}$ & $\begin{array}{l}\text { 0.0853 for Steel MRSF } \\
\mathbf{0 . 0 7 3 1} \text { for Concrete MRSF \& } \\
\text { Steel EBF } \\
\mathbf{0 . 0 4 8 8} \text { for all other buildings }\end{array}$ \\
\hline $\begin{array}{l}\text { 3.Seismic } \\
\text { Numerical } \\
\text { Coefficient }\end{array}$ & $\mathrm{C}=1.25 \mathrm{~S} / \mathrm{T}^{2 / 3}$ & $\begin{array}{l}C_{a}, C_{v} \& N_{a}, N_{v} \text { tables 208-7\& } \\
208-8\end{array}$ \\
\hline $\begin{array}{l}\text { 4.Occupancy } \\
\text { Importance } \\
\text { Factor } \\
\quad \text { ( I ) }\end{array}$ & $\begin{array}{l}\text { School as Standard } \\
\text { Occupancy } 1.0\end{array}$ & $\begin{array}{l}\text { School as Essential Facilities } \\
1.50\end{array}$ \\
\hline $\begin{array}{l}\text { 5.Numerical } \\
\text { Coefficient } \\
\text { of structural } \\
\text { system }\left(\mathrm{R}_{\mathrm{w}}\right. \\
\mathrm{R}) \text { for } \mathrm{RC} \\
\text { Bldgs. } \\
\end{array}$ & 10 & 8.50 \\
\hline $\begin{array}{l}\text { 6.Seismic } \\
\text { Zone Factor }\end{array}$ & Zone 2,Zone 3, Zone 4 & Zone 2 \& Zone 4 \\
\hline
\end{tabular}

Table 2 COMPARISON OF DESIGN BASE SHEAR (V)

(LSA and RSA Methods)

\begin{tabular}{|c|c|c|c|}
\hline Critical & NSCP & & \\
Orthogonal & 1992 & NSCP & \\
Direction & V & 2010 & \% Difference \\
\cline { 1 - 1 } Linear Static & (KN) & & \\
Analysis (LSA) & & & \\
\hline
\end{tabular}


Proc. of Sixth International Conference On Advances in Civil, Structural and Mechanical Engineering -ACSM 2017 Copyright $(\odot$ Institute of Research Engineers and Doctors, USA .All rights reserved.

ISBN: 978-1-63248-118-4 doi: 10.15224/ 978-1-63248-118-4-62

\begin{tabular}{|c|c|c|c|}
\hline Longitudinal Frame & 187.30 & 436.93 & $57.10 \%$ \\
\hline $\begin{array}{c}\text { Transverse Frame } \\
\text { Response Spectrum } \\
\text { Analysis (RSA) }\end{array}$ & \multicolumn{3}{|c|}{} \\
\hline Longitudinal Frame & 562.60 & $\begin{array}{c}2473.6 \\
0\end{array}$ & $77.26 \%$ \\
\hline Transverse Frame & 486.00 & $\begin{array}{c}2135.7 \\
0\end{array}$ & $71.23 \%$ \\
\hline
\end{tabular}

Table 3 MAXIMUM DEFLECTION AT CRITICAL BEAMS

(STAADPRo Results)

\begin{tabular}{|c|c|c|c|}
\hline \multirow[b]{2}{*}{ BEAM } & NSCP 1992 & NSCP 2010 & \multirow[t]{2}{*}{ \% DIFFERENCE } \\
\hline & \multicolumn{2}{|c|}{$\begin{array}{c}\text { Critical Displacement } \\
(\mathrm{mm})\end{array}$} & \\
\hline 420 & 6.452 & 36.964 & $82.54 \%$ \\
\hline 382 & 5.992 & 34.22 & $82.50 \%$ \\
\hline 402 & 6.50 & 34.50 & $81.16 \%$ \\
\hline 481 & 6.475 & 37.487 & $82.30 \%$ \\
\hline 242 & 2.552 & 19.520 & $86.90 \%$ \\
\hline 449 & 12.60 & 37.993 & $66.84 \%$ \\
\hline
\end{tabular}

Table 4 CRITICAL VALUE OF DESIGN ULTIMATE MOMENTS for the most critical beam. (From LSA \& MDM).

\begin{tabular}{|c|c|c|c|c|}
\hline $\begin{array}{c}\text { CRITICAL } \\
\text { ORTHOGONAL } \\
\text { DIRECTION }\end{array}$ & \multicolumn{2}{|c|}{$\begin{array}{c}\text { LONGITUDINAL } \\
\text { FRAME }\end{array}$} & \multicolumn{2}{c|}{$\begin{array}{c}\text { TRANSVERSE } \\
\text { FRAME }\end{array}$} \\
\hline & $\begin{array}{c}\text { NSCP } \\
1992\end{array}$ & $\begin{array}{c}\text { NSCP } \\
\mathbf{2 0 1 0}\end{array}$ & $\begin{array}{c}\text { NSCP } \\
1992\end{array}$ & $\begin{array}{c}\text { NSCP } \\
\mathbf{2 0 1 0}\end{array}$ \\
\hline & \multicolumn{2}{|c|}{ BEAM 262 } & \multicolumn{2}{c|}{ BEAM 268 } \\
\hline SEISMIC MOMENTS & 61.52 & 143.46 & 97.10 & 225.90 \\
\hline $\begin{array}{c}\text { (DL + LL) } \\
\text { FACTORED } \\
\text { MOMENTS }\end{array}$ & 278.20 & 278.20 & 203.10 & 203.10 \\
\hline COMBINED Mu & 339.72 & 421.66 & 300.20 & 429.00 \\
\hline \% DIFFERENCE & \multicolumn{2}{|c|}{$\mathbf{2 4 . 1 0}$} & \multicolumn{4}{|c|}{$\mathbf{4 2 . 9 0}$} \\
\hline
\end{tabular}

Table 3 shows that the maximum deflections at critical beams element are higher by $80.37 \%$ (average) under NSCP 2010 than those under NSCP 1992. The Design Base Shear is higher by $57 \%$ and $77 \%$ under NSCP 2010 using LSA and RSA respectively than those under NSCP 1992 as shown in Table 2. The Ultimate Design Moments, $(\mathrm{Mu})$ in tension for the most critical beam is higher by 86.9\% in NSCP 2010 than in NSCP 1992.

The major findings of the research study are:
The effects of the Seismic Provisions of NSCP 2010 on the value of Design Base Shear is greater than the effects of NSCP 1992 Seismic Provisions.

The Elastic Response Parameters of Structural elements have higher values in NSCP 2010 than in NSCP 1992 Seismic Provisions.

The resulting sections and reinforcements of structural elements are higher in NSCP 2010 than in NSCP 1992.

\section{CONCLUSION and RECOMMENDATIONS}

NSCP 2010 seismic provisions imposed on the Three- Storey Reinforced Concrete School Building have higher values of Design Base Shear (V) than in NSCP 1992.This indicated that NSCP 2010 were more conservative and cautious in terms of the safety and structural integrity of the school building.

The higher values of Elastic Response Parameter (ERP) and the larger sizes of structural elements and its reinforcement in NSCP 2010 enhanced the structural safety of the Three-Storey Reinforced Concrete School Building against severe earthquake.

The structural safety of the Three-Storey Reinforced Concrete Building designed under the seismic provisions of NSCP 2010 were given due consideration wherein it should not collapse but with minimal non-structural damage only during a severe earthquake while NSCP 1992 give more emphasis on the economic aspect of design but with the possibility of structural damage and even collapse during the occurrence of the same earthquake.

In relation with the findings and conclusions of this research, the recommendations are:

Seismic structural assessment of existing Reinforced Concrete Public School buildings in the Philippines designed under NSCP 1992 located in areas with high seismicity shall be done to avert further damage, loss of life and properties during the occurrence of an earthquake.

Structural strengthening and retrofitting of existing public school building that were designed under NSCP 1992 seismic provisions shall be 
undertaken to improve its worthiness during severe earthquake.

The selection of regular building configurations and the application of sound detailing principles are more likely to provide the required level of securing the building against collapse during an earthquake than detailed refinement of the analysis techniques, thereby the specific rules for a conceptual design for earthquake resistant buildings must strictly be followed

\section{REFERENCES}

[1] Chopra, Anil K.(1995). Dynamics of Structures, (pp.474-530) International Edition, New Jersey, USA: Prentice Hall

2. Chopra,Anil K \& Goel Rakesh K. (1991) Evaluation of US Seismic Code Provisions for Assymetric Plan System, Structural Division,ASCE,117 (12),(pp3762-3782)

[3] Mahaylov,B.(2006) Analysis of Code Procedures for Seismic Assessment of Existing Building,.Ph.D._Dissertation, European School of Advanced Studies in Reduction of Seismic Risk. Rose School, Universita degli Studi di Pavia, Pavia, Italy
[4] Ongaro, L (2007) Comparing Italian Seismic Codes for the Design of Reinforced Frame Building, (pp.12-42 and p.144) Masteral Thesis, Instituto Universitario di Studi Superiori and Universita degli Studi di Pavia, Pavia, Italy.

[5] Oreta, W (2006) Basic Structural Performance Index of Earthquake Damaged RC Buildings: Technical Proceedings of Asia- Pacific Conference on Earthquake Engineering 2006 (pp.186-187) Manila, Philippines.

[6] Torregosa,R., Sugito, M., \& Nojima,N.,(2001) Strong Motion Simulation for the Philippines based on Seismic Hazard Assessment, Journal on Natural Disaster Science, Vol.23 No.1, 2001 pp.1889-1902

[7] Yamazaki, F., \& Molas G., (1992) Seismic Hazard Analysis using Earthquake Occurrence Data, Earthquake Engineering Tenth World Conference 1992, Balkema, Rotterdam

[8] National Structural Code of the Philippines (NSCP) $19924^{\text {th }}$ edition, Association of Structural Engineers of the Philippines (ASEP), Manila, Phils.

[9] National Structural Code of the Philippines (NSCP) $20106^{\text {th }}$ edition, (ASEP), Manila, Phils.

[10] American Concrete Institute (ACI 318-08), ACI Committee 318

[11] STAADPro Version 2005, Bldg. 1001 US, Proprietary Program Research Engineers International, User ID (LZO+LND) 